\title{
Pipoxolan Exhibits Antitumor Activity Toward Oral Squamous Cell Carcinoma Through Reactive Oxygen Species-mediated Apoptosis
}

\author{
PEI-YU CHOU ${ }^{1,2}$, MIN-MIN LEE ${ }^{3}$, SUNG-YUAN LIN $^{4}$ and MING-JYH SHEU ${ }^{4}$ \\ ${ }^{1}$ Department of Nursing, Hung Kuang University, Taichung, Taiwan, R.O.C.; \\ ${ }^{2}$ Sports Recreation and Health Management Continuing Studies - Bachelor's Degree Completion Program, \\ Tung Hai University, Taichung, Taiwan, R.O.C.; \\ ${ }^{3}$ Department of Health and Nutrition Biotechnology, Asia University, Taichung, Taiwan, R.O.C.; \\ ${ }^{4}$ School of Pharmacy, China Medical University, Taichung, Taiwan, R.O.C.
}

\begin{abstract}
Pipoxolan is frequently prescribed as a smooth muscle relaxant. Pipoxolan has also been shown to have anticancer activity. Our study investigated whether pipoxolan induced apoptosis in oral squamous cell carcinoma (OSCC). Cell cytotoxicity was evaluated by the MTT assay. Cell apoptosis and cell-cycle distribution were measured by annexin V/propidium iodide (PI) double staining and flow cytometry, respectively. Apoptotic-related proteins were assessed by western blotting. Reactive oxygen species (ROS) generation and mitochondrial membrane potential (MMP) were measured with fluorescent probes. Following exposure of TW206 OSCC cells to pipoxolan, a time-dependently decrease in MMP and an increase in ROS were observed. However, these effects were significantly abrogated by the free radical scavenger $N$-acetylL-cysteine. Since high levels of ROS were produced early in the treatment, intracellular ROS seemed to play a key role in pipoxolan-induced apoptosis. In HSC-3 OSCC cells, our results demonstrated that pipoxolan treatment caused a timedependent increase of protein expression of active caspase-3 and -9 , cytosolic cytochrome c, cleavage of poly (ADP-ribose) polymerase, and B-cell lymphoma 2 (BCL2)-like protein 4 $(B A X)$. However, expression of BCL2 itself was reduced. Clearly, such an increase in BAX/BCL2 ratio would be associated with apoptosis. In addition, pipoxolan markedly suppressed the protein expression of phosphatidylinositol-4,5bisphosphate 3-kinase (PI3K) and phosphorylation of protein
\end{abstract}

Correspondence to: Ming-Jyh Sheu, School of Pharmacy, China Medical University, Taichung, 404, Taiwan R.O.C. Tel: +886 422053366, ext. 5158, Fax: +886 422078083, e-mail: hsumj@ mail.cmu.edu.tw

Key Words: Pipoxolan, reactive oxygen species, apoptosis, caspase3, OSCC. kinase $B(A K T)$. These data suggest that pipoxolan acts against HSC-3 in vitro via intrinsic apoptotic signaling pathways, and inhibition of PI3K/AKT signaling.

Oral squamous cell carcinoma (OSCC) is a major health issue and mostly predominant in South East Asia. More than 200,000 new cases are reported annually worldwide. each year. Although much research on treatment strategies have been carried out, the 5-year survival rate of patients with OSCC is still less than $50 \%$ (1). Indeed, combined surgical resection with chemotherapy significantly improves the effectiveness of treatment and reduces the recurrence rate in patients with OSCC (2), however, cancer cells become resistant to chemotherapeutic agents. Accordingly, it is necessary to search for new agents for the treatment of OSCC.

Oxidative stress occurs when there is an imbalance between reactive oxygen species (ROS) and the body's antioxidant-scavenging mechanisms (3). Studies have shown that elevated oxidative stress can induce carcinogenesis in various types of cancer, and potential treatment strategies that target ROS have been investigated (4). Additionally, studies have confirmed that oxidative stress is correlated with the development of OSCC (5). However, anticancer agents have been demonstrated to induce the death of OSCC through apoptosis (6), that can be activated by DNA damage and an increase in the level of ROS (7). Upon such stimulation, cytochrome $c$ is released from mitochondria into the cytoplasm. This leads to the activation of caspase-9, caspase-3, and poly (ADP-ribose) polymerase (PARP) and causes apoptosis (8). The cleavage at Asp residues that separate the large and small subunits (i.e. caspase-9) leads to the activation of an effector caspase (i.e. caspase-3) (9).The caspases are mainly produced as zymogens, and become activated by two pathways during apoptosis (10). Regulated by the B-cell lymphoma 2 (BCL2) family, the signal of the 
intrinsic pathway stimulates cytochrome $c$ translocation from the mitochondria to the cytoplasm, and stimulates caspase-9 activation. The extrinsic pathway involves the activation of ligands of the tumor necrosis factor (TNF) family or FAS (11). FAS-associated death domain protein (FADD) activates caspase- 8 . Thereafter, both caspase- 8 and -9 have been shown to cleave and activate the proenzyme of caspase-3, which initiates cellular destruction by cleaving PARP (12).

Study suggests that the epidermal growth factor receptor (EGFR)/phosphoinositide 3-kinase (PI3K)/protein kinase B $(\mathrm{AKT}) /$ mammalian target of rapamycin pathway is strongly linked with the progression and development of head and neck squamous cell carcinoma (HNSCC) (13). Targeting EGFR-PI3K-AKT-mTOR pathway activation increased radiosensitivity in HNSCC, showing promising outcome (14). The anticancer agent esculetin alone (15) or in combination with chemotherapeutic agents (16) was shown to induce apoptosis of OSCC cells.

5,5-Diphenyl-2-( $\beta$ - $N$-piperidinoethyl)-1,3-dioxolan-4-onehydrochloride (pipoxolan hydrochloride, Rowapraxin ${ }^{\circledR}$; $\mathrm{MW}=387.5$; Figure 1) is commonly prescribed as a smooth muscle relaxant, and has many different activities including anti-spasmodic, digestive analgesic and anti-migraine $(17,18)$. Pipoxolan has also been shown to have anticancer activity, including against human leukemia $\operatorname{HL}-60(19,20)$ and non-small lung cancer cells (21). Pipoxolan has also been shown to protect from ischemia/reperfusion-induced cerebral infarction, carotid artery ligation-induced intimal hyperplasia and affects vascular smooth muscle cell migration both in vivo and in vitro (22). In this study, we aimed to investigate the impact of pipoxolan on cytotoxicity toward OSCC cells and explored possible molecular mechanisms of action.

\section{Materials and Methods}

Materials. Antibodies to caspase-3, -8 and -9 were purchased from Cell Signaling (Boston, MA, USA); those to cleaved PARP, PI3K, AKT, pAKT, B-cell lymphoma 2 (BCL2)-like protein 4 (BAX) and BCL2 were obtained from Santa Cruz (Santa Cruz, CA, USA); antibody to cytochrome $c$ was purchased from BioLegend (San Diego, CA, USA). Secondary antibodies were acquired from Amersham Biosciences (Freiburg, Germany). All other chemicals were obtained from Sigma (Saint Louis, MO, USA). Pipoxolan was provided by Chin Teng Pharmaceutical Ind. Co., Ltd. (Dachia, Taiwan).

Cell culture. The cancer cell lines were obtained from the Food Industry Research and Development Institute (Hsinchu, Taiwan). Cal-27, HSC-3 and TW206 cells were cultured in RPMI-1640 medium containing $2 \mathrm{mM}$ L-glutamine, $100 \mathrm{U} / \mathrm{mL}$ penicillin, 100 $\mu \mathrm{g} / \mathrm{mL}$ streptomycin (Sigma-Aldrich, St. Louis, MO, USA), and $10 \%$ fetal bovine serum (FBS; Invitrogen, Carlsbad, CA, USA) in a humidified atmosphere containing $5 \% \mathrm{CO}_{2}$ at $37^{\circ} \mathrm{C}$. All experiments were conducted using exponentially growing cells cultured in complete medium with $1 \%$ FBS. To prevent cell overgrowth, the initial cell density was $1 \times 10^{5}$ cells $/ \mathrm{mL}$ for $48 \mathrm{~h}$ treatment. Pipoxolan was prepared freshly in dimethyl sulfoxide (DMSO; Sigma-Aldrich, St. Louis, MO, USA) before each experiment. The final DMSO concentration in all experiments was $0.1 \%$ and had negligible effect on the measured parameters, including mitochondrial membrane potential (MMP). Negative controls were treated with $0.1 \%$ DMSO only. For treatments with inhibitor, $2.5 \times 105$ cells $/ \mathrm{mL}$ were seeded into 24-well plates for 24 $\mathrm{h}$, then pretreated with $10 \mathrm{mM} \mathrm{N}$-acetylcysteine (NAC, antioxidant; Sigma-Aldrich) for $1 \mathrm{~h}$, followed by treatment with or without pipoxolan $(20 \mu \mathrm{g} / \mathrm{mL})$.

3-(4,5-Dimethylthiazol-2-yl)-2,5-diphenyl tetrazolium bromide (MTT) assay. This assay was conducted according to our previous report (20) with slight modification. Exponentially growing human OSCC cells were seeded at a density of $2 \times 10^{5}$ cells $/ \mathrm{mL}$ for $24 \mathrm{~h}$, and then cells were treated with different doses of pipoxolan (1.6, $3.2,6.25,12.5,25,50$ and $100 \mu \mathrm{g} / \mathrm{mL}$ ) for $24 \mathrm{~h}$. Then, $20 \mu \mathrm{L}$ of MTT solution $(5 \mathrm{mg} / \mathrm{mL})$ was added, and the cells were incubated for an additional $3 \mathrm{~h}$. The resulting formazan precipitate was dissolved in $200 \mu \mathrm{L}$ of DMSO, and the solution was vigorously mixed to dissolve the reacted dye. The absorbance of each well was read on a multi-plate reader at $570 \mathrm{~nm}$ by a spectrophotometer (BioTek, Winooski, VT, USA).

Quantification of apoptosis using flow cytometry. This assay was conducted according to our previous report (20) with slight modification. Cells were seeded at a density of $2 \times 10^{5}$ cells/well in a 24-well plate (Falcon, Franklin Lakes, NJ, USA) and treatment with different doses of pipoxolan for $24 \mathrm{~h}$. In the time course study, TW206 and HSC-3 cells were treated with $20 \mu \mathrm{g} / \mathrm{mL}$ in and $50 \mu \mathrm{g} / \mathrm{mL}$, respectively, for different time periods $(0,8,12,24$ and $48 \mathrm{~h}$ ). The cells were washed twice with ice-cold $1 \times$ phosphatebuffered saline (PBS) before being fixed in 70\% ethanol overnight. Cells were centrifuged $(3000 \times g$ for $5 \mathrm{~min}$ at room temperature) and resuspended in $0.3 \mathrm{ml}$ of DNA staining solution $[100 \mu \mathrm{g} / \mathrm{ml}$ propidium iodide (PI), $0.2 \% \mathrm{NP}-40$, and $1 \mathrm{mg} / \mathrm{mL}$ RNase A (DNase-free) in PBS lacking $\mathrm{Ca}^{++}$and $\mathrm{Mg}^{++}$; at a 1:1:1 ratio by volume] for a minimum of $30 \mathrm{~min}$ in a dark room and analyzed within $2 \mathrm{~h}$. Cells were analyzed using flow cytometry (FACS) Calibur $^{\mathrm{TM}}$ system (Becton Dickinson, San Jose, CA, USA). Ten thousand events were acquired and DNA content was determined using DNA analysis software ModFitLT, version 3.0 (Verity Software, Topsham, ME, USA).

Annexin-V/PI double staining. This assay was conducted according to our previous report (20) with slight modification. TW206 cells were seeded at a density of $2 \times 10^{5}$ cells/well in a $24-$ well plate (Falcon) and treated with $20 \mu \mathrm{g} / \mathrm{ml}$ pipoxolan for different time periods (2, 4, and $6 \mathrm{~h}$ ). For annexin-V staining, a commercially available kit for the FACS Calibur ${ }^{\mathrm{TM}}$ system was used (BioSource, Camarillo, CA, USA) . In brief, the cells were washed twice in PBS buffer and resuspended at $100 \mu \mathrm{l} /$ tube $1 \mathrm{x}$ annexin-V binding buffer. The cells were then stained with $5 \mu \mathrm{l}$ of annexin- $\mathrm{V}$ fluorescein isothiocyanate and $10 \mu \mathrm{l}$ of PI buffer to each tube. After incubation for $15 \mathrm{~min}$ in the dark at room temperature, cells were diluted with $400 \mu \mathrm{l} 1 \mathrm{x}$ annexin-V binding buffer and then measured without gating within $1 \mathrm{~h}$ with a FACS Calibur $^{\mathrm{TM}}$ system (Becton Dickinson). 


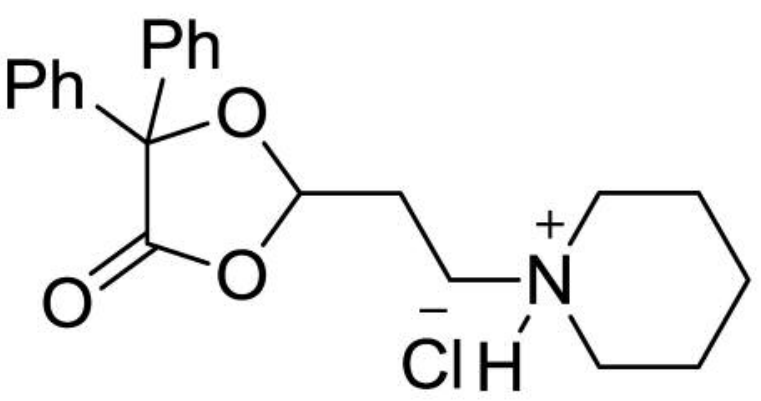

Figure 1. Chemical structure of pipoxolan.

Flow cytometric analysis of ROS and MMP. This assay was conducted according to our previous report with modification (20). Cells were cultured at a density of $2.5 \times 10^{5} / \mathrm{ml}$ in 24 -well plates, then pipoxolan $(20 \mu \mathrm{g} / \mathrm{ml})$ was added and plates incubated for a further 1,3 and $6 \mathrm{~h}$ respectively. After pipoxolan treatment, ROS were assessed using a fluorescent dye, 2',7'-dichlorodihydrofluorescein diacetate $\left(\mathrm{H}_{2}\right.$-DCF-DA) (Molecular Probes, Eugene, OR, USA), which is converted to 2',7'-dichlorofluorescein (DCF) by esterases when taken up. ROS were then analyzed with the FACS Calibur $^{\mathrm{TM}}$ system (Becton Dickinson). A fluorometric probe, 3,3'-dihexyloxacarbocyanine iodide $\left(\mathrm{DiOC}_{6}\right)$, was applied to determine the MMP (23). Briefly, OSCC cells were plated in 6-well culture dishes. When reaching confluence, the cells were treated with vehicle or pipoxolan for $24 \mathrm{~h}$. OSCC cells were subsequently stained with $\mathrm{DiOC}_{6}(40 \mathrm{nM})$ for $15 \mathrm{~min}$ at $37^{\circ} \mathrm{C}$. Cells were then collected, washed twice in PBS, and analyzed with FACS Calibur ${ }^{\mathrm{TM}}$ system (Becton Dickinson).

Western blot analysis. This assay was conducted according to our previous report with slight modification (20). TW206 and HSC-3 cells were plated in 10-cm dishes in RPMI containing $1 \%$ FBS at a density of $5 \times 10^{6}$ cells and incubated with $20 \mu \mathrm{g} / \mathrm{ml}$ or $50 \mu \mathrm{g} / \mathrm{ml}$ of pipoxolan, respectively for $2,4,8,12,24$ and $48 \mathrm{~h}$. The cells were collected, then lysed in a lysis solution $(6.25 \mathrm{ml}$ Tris- $\mathrm{HCl}, \mathrm{pH} 6.8$. $10 \mathrm{ml} \mathrm{10 \%} \mathrm{sodium} \mathrm{dodecyl} \mathrm{sulfate} 8.3 \mathrm{ml}$ dithiothreitol) followed by incubation at $95^{\circ} \mathrm{C}$ for $5 \mathrm{~min}$. Samples were separated in a $12 \%$ polyacrylamide gel and then transferred onto polyvinylidene difluoride membrane. The membrane was blocked in 5\% non-fat milk in PBS-Tween 20 buffer for $1 \mathrm{~h}$. and probed with antibodies specific for p53, BAX, BCL2, cytochrome c, caspase-9, caspase-8, caspase- 3 and cleaved PARP overnight at $4^{\circ} \mathrm{C}$. The blots were then incubated with horseradish peroxidase-linked secondary antibody for $1 \mathrm{~h}$. followed by development with the electrochemi-luminsence reagent (Invitrogen, Carlsbad, CA, USA) and exposure to Hyperfilm (Amersham, Arlington Height, IL, USA). The data were analyzed by Fujifilm Las-4000 system (Fujifilm Co. Tokyo, Japan).

Statistical analysis. Values are presented as the mean \pm SEM Statistical analysis of differences between two groups was performed using Student's $t$-test. Statistical comparison of more than two groups was performed using one-way analysis of variance (ANOVA) with Bonferroni's post hoc test. In all cases, $p<0.05$ was considered significant.

\section{Results}

Effects of pipoxolan on cell viability of human TW206, HSC3 and Cal-27 cells. In the MTT assay, the relative cell viability at different concentrations of pipoxolan after $24 \mathrm{~h}$ was measured. Pipoxolan displayed cytotoxicity toward OSCC (TW206, HSC-3) and HNSCC (Cal-27) cells. The $\mathrm{IC}_{50}$ values for TW206, HSC-3 and Cal-27 were 13.13 $\mu \mathrm{g} / \mathrm{mL}, 42.28 \mu \mathrm{g} / \mathrm{mL}$ and $52.69 \mu \mathrm{g} / \mathrm{mL}$, respectively (Figure $2 \mathrm{~A}$ and B). TW206 and HSC-3 cell lines were especially sensitive to pipoxolan, further studies were performed on these cell lines.

Effects of pipoxolan on phosphatidylserine externalization of TW206 cells. Treatment of TW206 and HSC-3 cells with 20 $\mu \mathrm{g} / \mathrm{mL}$ of pipoxolan induced the translocation of phosphatidylserine from the cell membrane (inner layer) to the outer layer as shown by annexin V/PI double staining assay. Our results demonstrate that apoptosis was detected at $2 \mathrm{~h}$ of pipoxolan treatment, however, the highest level was not reached until $6 \mathrm{~h}$ of pipoxolan treatment (Figure 2C).

Effects of pipoxolan on the cell cycle in TW206 and HSC-3 cells. To determine whether pipoxolan-induced cytotoxicity involves alterations in cell-cycle progression of TW206 and HSC-3 cells, flow cytometric analyses were conducted. Our results show that pipoxolan $(15 \mu \mathrm{g} / \mathrm{mL})$ caused significant apoptosis of TW206 cells (Figure 3A). Pipoxolan at 20 and $25 \mu \mathrm{g} / \mathrm{mL}$ for $24 \mathrm{~h}$ led to an even higher percentage of hypodiploid cells (sub- $\mathrm{G}_{1}$ fraction) than in control cells. The maximal degree of apoptosis in TW206 cells was seen after $24 \mathrm{~h}$ of pipoxolan treatment at $25 \mu \mathrm{g} / \mathrm{ml}$ (Figure 3B). Moreover, pipoxolan (20 and $25 \mu \mathrm{g} / \mathrm{ml}$ ) treatment for $24 \mathrm{~h}$ caused a significant decrease of TW206 cells at $\mathrm{G}_{0} / \mathrm{G}_{1}$ phase (Figure 3B). Moreover, pipoxolan induced HSC-3 cell apoptosis in dose- and time-dependent manners (Figure 3D and E). The results show that pipoxolan $(25 \mu \mathrm{g} / \mathrm{ml})$ caused significant apoptosis of HSC-3 cells. Pipoxolan at 50 and $100 \mu \mathrm{g} / \mathrm{ml}$ for $24 \mathrm{~h}$ led to a higher percentage of hypodiploid cells than in control cells (Figure 3E). Furthermore, these treatments caused a significant decrease of HSC-3 cells at $\mathrm{G}_{0} / \mathrm{G}_{1}$ phase (Figure 3D).

Pipoxolan-induced apoptosis in TW206 cells was accompanied by an increase in ROS production and the loss of MMP. We examined the effects of pipoxolan on ROS production and loss of MMP by using the ROS-specific dye DCFH-DA and mitochondria-specific dye $\mathrm{DiOC}_{6}$, respectively. Although the highest levels were not reached until $6 \mathrm{~h}$, an increase in DCFH fluorescence in TW206 cells was detected of early as $2 \mathrm{~h}$ after pipoxolan adminstration (Figure 4A). In order to explore whether oxidative stress is essential for pipoxolan-mediated apoptosis, cells were pre-treated with the free radical scavenger 


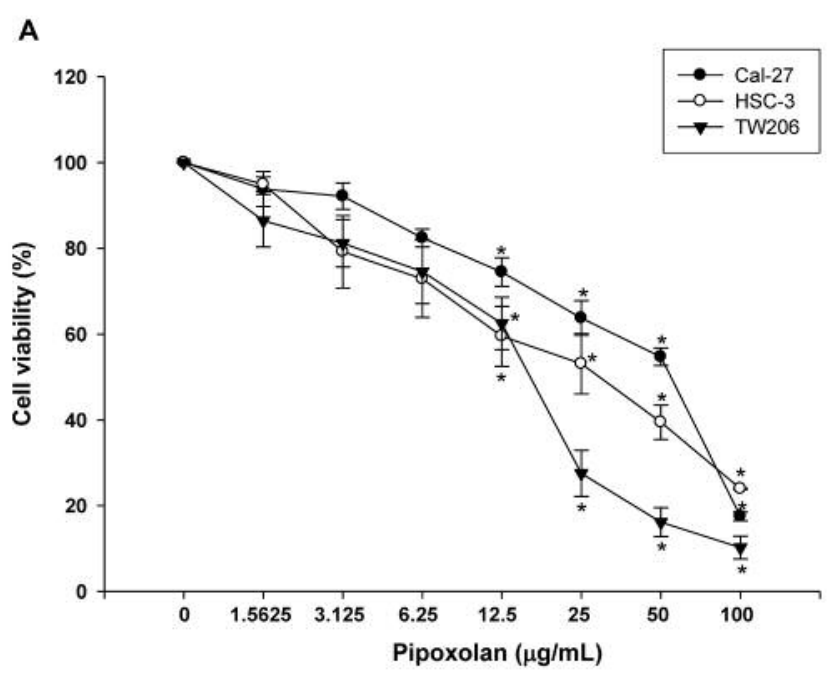

B

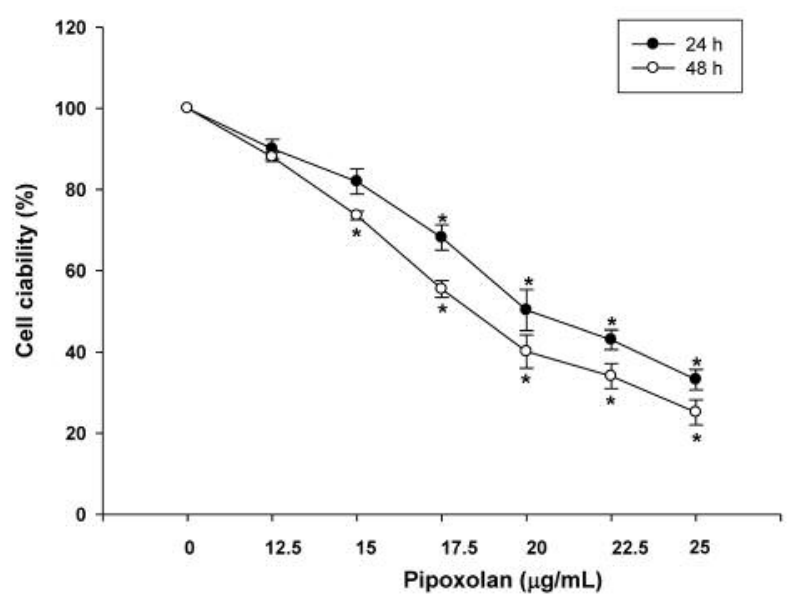

C
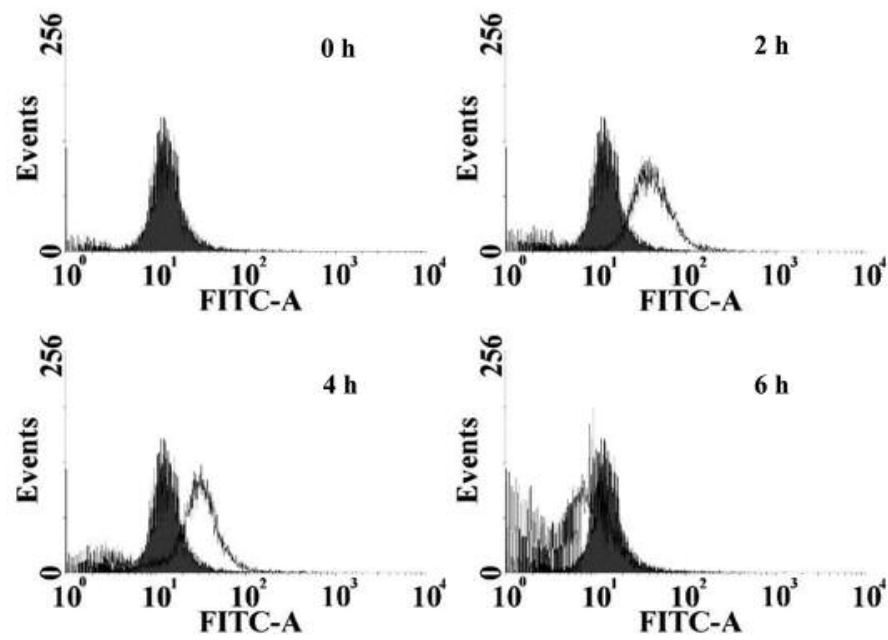

Figure 2. A: Pipoxolan induces apoptosis of human oral squamous cell carcinoma cells. TW206, HSC-3 and Cal-27 cells were treated with pipoxolan at the indicated concentrations for $24 \mathrm{~h}$. Cell viability was assessed by 3-(4,5-dimethylthiazol-2-yl)-2,5-diphenyl tetrazolium bromide assay. Optical density was determined at $570 \mathrm{~nm}$ and cell survival data are expressed as a percentage of that relative to the control. B: Cytotoxic effects of pipoxolan on TW206 cells. TW206 cells were was treated with different concentrations of pipoxolan for 24 and 48 h. C: Effect of pipoxolan on phosphatidylserine externalization (annexin V binding) in TW206 cells. TW206 cells were treated with $20 \mu \mathrm{g} / \mathrm{ml}$ pipoxolan for 2, 4 and 6 h. Cells were incubated with annexin V-fluorescein isothiocyanate (FITC) and propidium iodide (PI) followed by flow cytometry.

NAC (10 mM). As shown, NAC significantly reduced pipoxolan-induced TW-206 cytotoxicity (Figure 4B). These findings suggest that ROS generation maybe crucial for pipoxolan-induced cell death. A remarkable decrease in MMP was observed in TW206 cells after 1-6 h of exposure to pipoxolan $(20 \mu \mathrm{g} / \mathrm{ml}$ ) (Figure $4 \mathrm{C}$ ). Our data showed that pipoxolan triggered apoptosis of TW206 cells through the increase of ROS production and the disruption of MMP.
Pipoxolan-induced apoptosis is mediated through mitochondrial apoptotic pathways in TW206 and HSC-3 cells. We determined whether pipoxolan induces apoptosis through the intrinsic signaling pathway. Pipoxolan treatment at 50 $\mu \mathrm{g} / \mathrm{ml}$ caused a time-dependent increase of cytochrome $c$ in HSC-3 cells. Pipoxolan induced the release of cytochrome $c$ from mitochondria and stimulated the cleavage of procaspase-9 into $35 \mathrm{kDa}$ active fragments of caspase-9 (Figure 

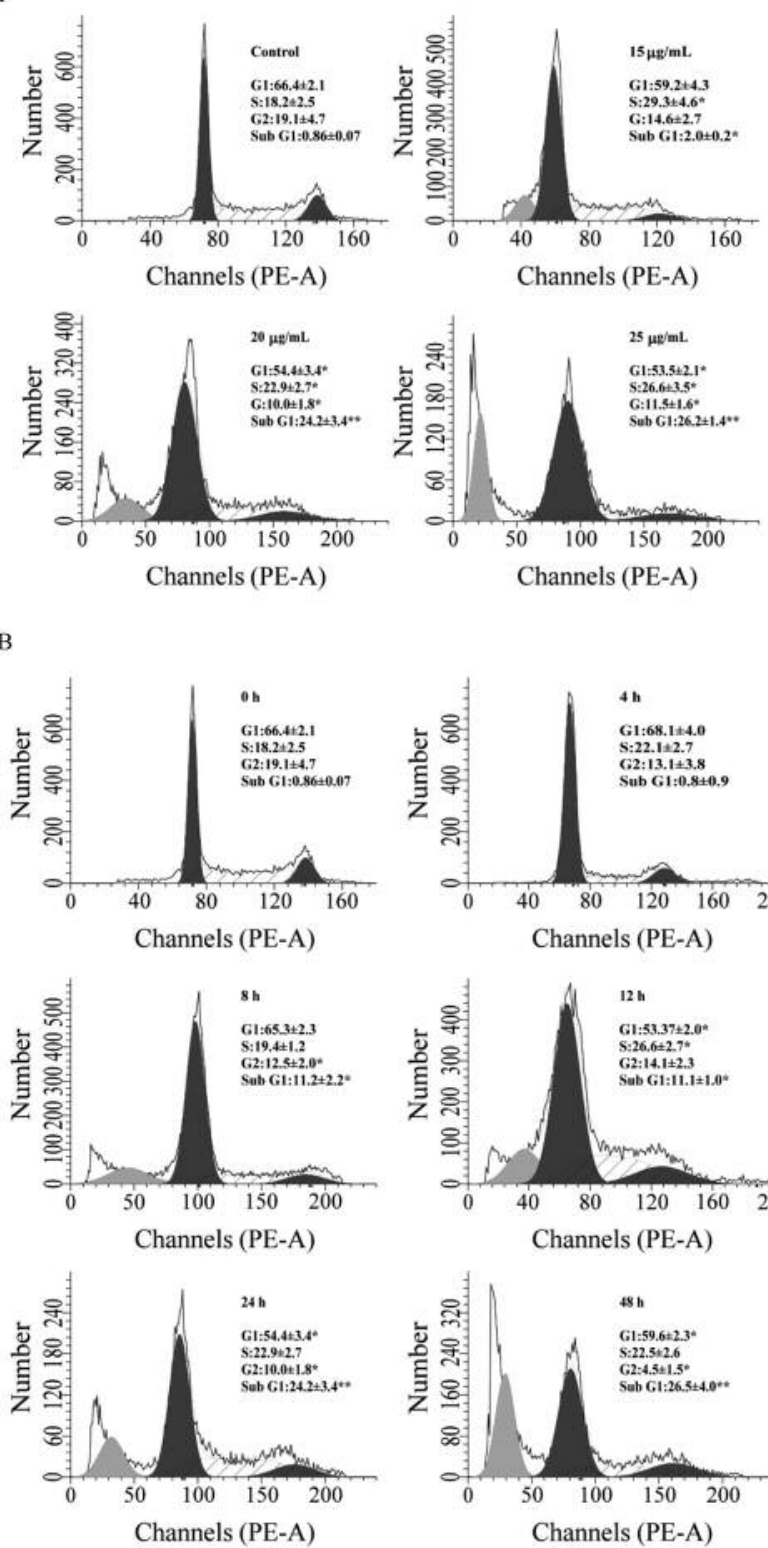
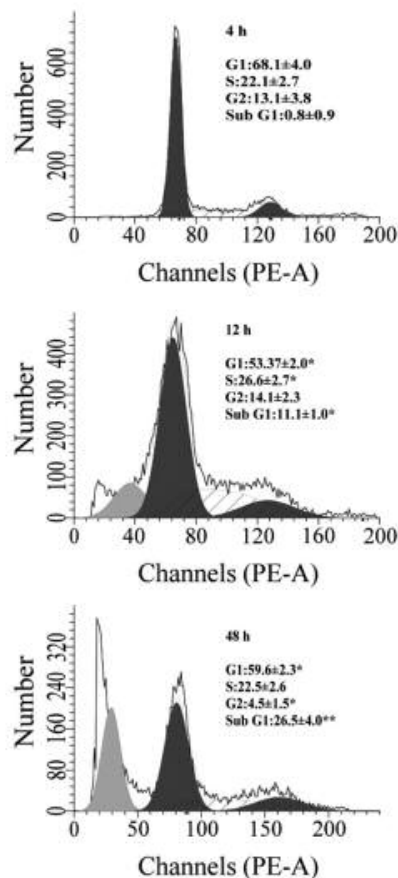

C
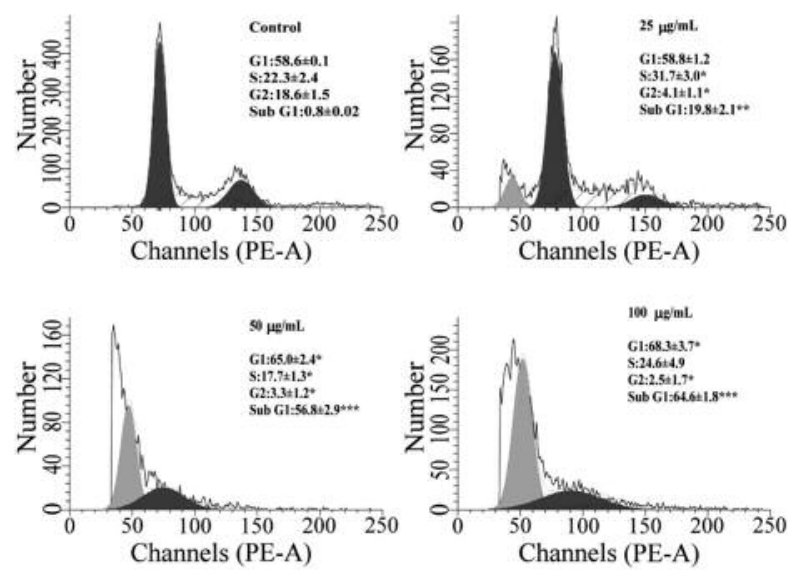

D
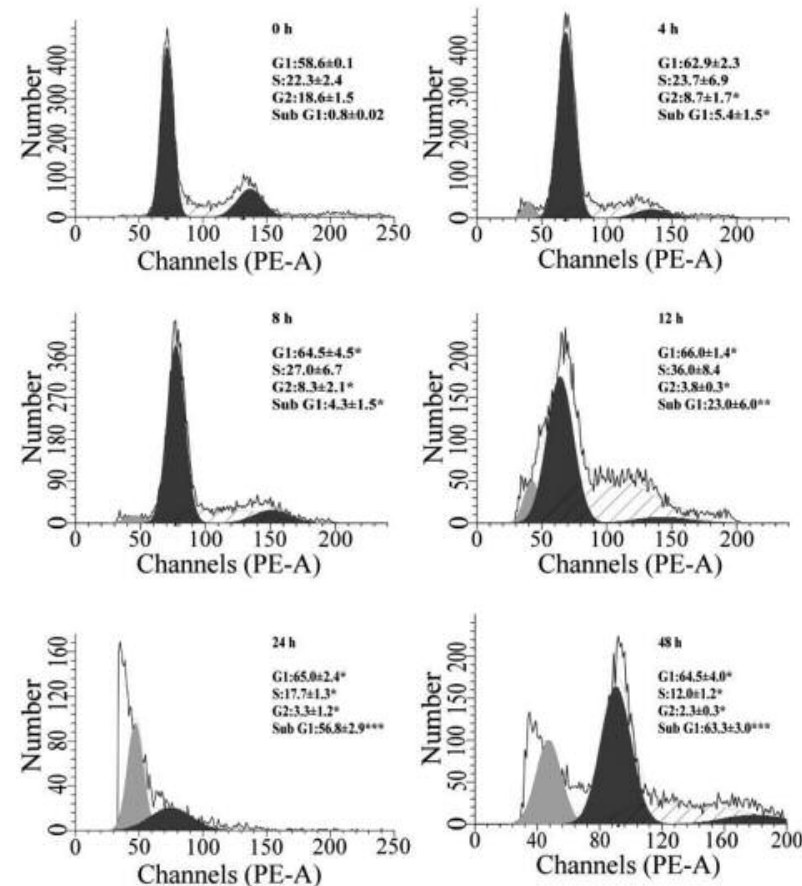

Figure 3. Determination of the proportion of sub-G $G_{1}$ cells following pipoxolan treatment of TW206 and HSC-3 cells, as determined by flow cytometry. A: TW206 cells were treated with 15, 20 and $25 \mu \mathrm{g} / \mathrm{ml}$ pipoxolan for $24 \mathrm{~h}$. B: TW206 cells were treated with $20 \mu \mathrm{g} / \mathrm{mL}$ pipoxolan for 4, 8, 12,24 and $48 \mathrm{~h}$. C: HSC-3 cells were treated with 25,50 and $100 \mu \mathrm{g} / \mathrm{ml}$ pipoxolan for $24 \mathrm{~h}$. D: HSC-3 cells were treated with $50 \mu \mathrm{g} / \mathrm{mL}$ pipoxolan for 4 , $8,12,24$ and 48 h. Data are means \pm SEM of three experiments. ${ }^{*} p<0.05, * * p<0.01, * * * p<0.001$, significantly increased versus control. PE-A: Phycoerythrin-A.

5) and of pro-caspase- 3 into $17 \mathrm{kDa}$ fragments of caspase- 3 (Figure 5). Finally, PARP was effectively hydrolyzed to the 85-kDa fragment of cleaved PARP in HSC-3 cells (Figure 5). Our data show that pipoxolan treatment caused OSCC apoptosis through the activation of caspases-9, and -3 , however, caspases-8 was not involved in pipoxolan-induced apoptosis (data not shown).
We examined whether pipoxolan-induced apoptosis is associated with BCL2 family proteins, which are the important regulator proteins for the activation of the caspase cascade. The expression of the pro-apoptotic factor BAX significantly increased in TW206 and HSC-3 cells after $24 \mathrm{~h}$ incubation with 20 and $50 \mu \mathrm{g} / \mathrm{ml}$ pipoxolan, respectively. That of BCL2 significantly decreased after $24 \mathrm{~h}$ incubation 
A
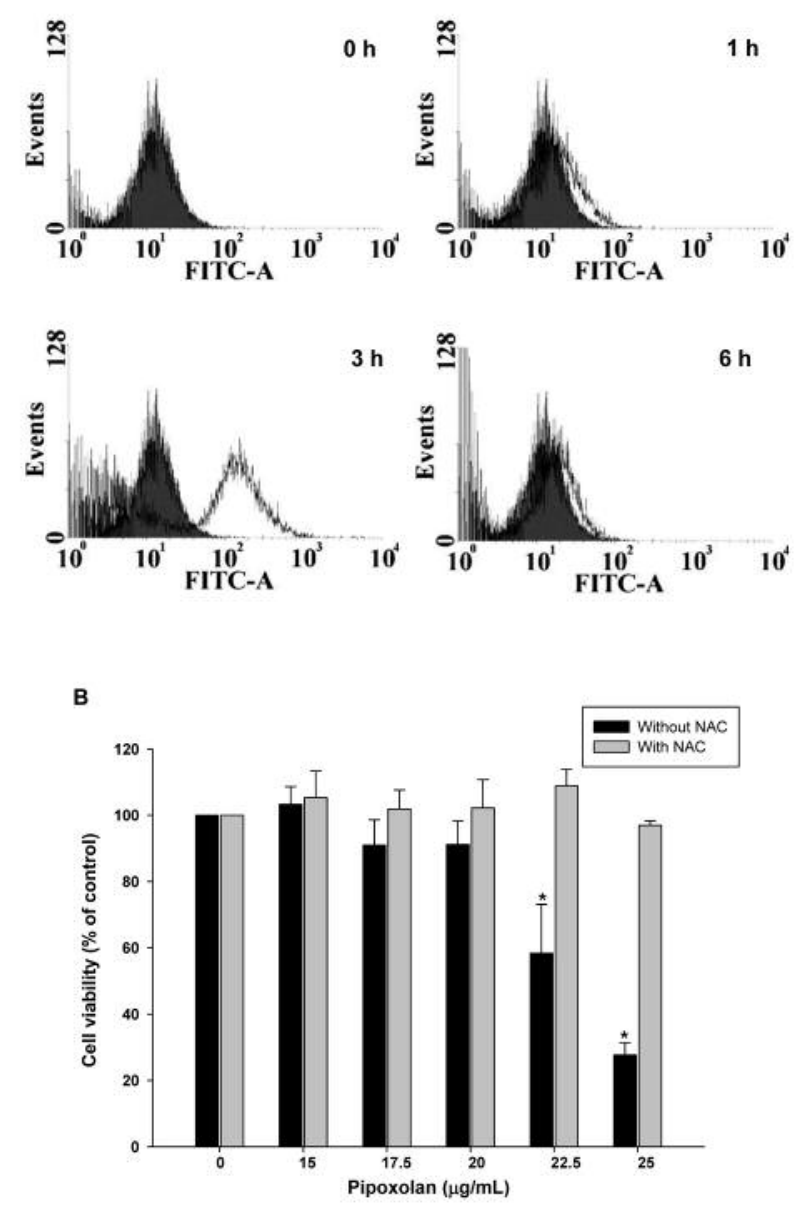

with 20 and $50 \mu \mathrm{g} / \mathrm{ml}$ pipoxolan treatment in the TW206 and HSC-3 cancer cell lines, respectively (Figure 5).

Effect of pipoxolan on PI3K, AKT, and phosphorylated AKT expression in TW206 and HSC-3 cells. To further investigate the involvement of PI3K/AKT, an experiment was conducted to measure the expression of PI3K/AKT signaling upon pipoxolan treatment. Our results demonstrate that incubation of TW206 and HSC-3 cells with pipoxolan $(20$ and $50 \mu \mathrm{g} / \mathrm{ml})$ led to a time-dependent decrease of PI3K and pAKT levels. Notably, after incubation for $24 \mathrm{~h}$, pipoxolan had significantly suppressed PI3K and pAKT (Figure 5).

\section{Discussion}

Initial treatment for OSCC is surgery, then, radiation with/without chemoradiation is added postoperatively for highrisk patients. Currently, docetaxel, cisplatin-based and 5fluorouracil are the standard therapeutical regimen for OSCC,
C
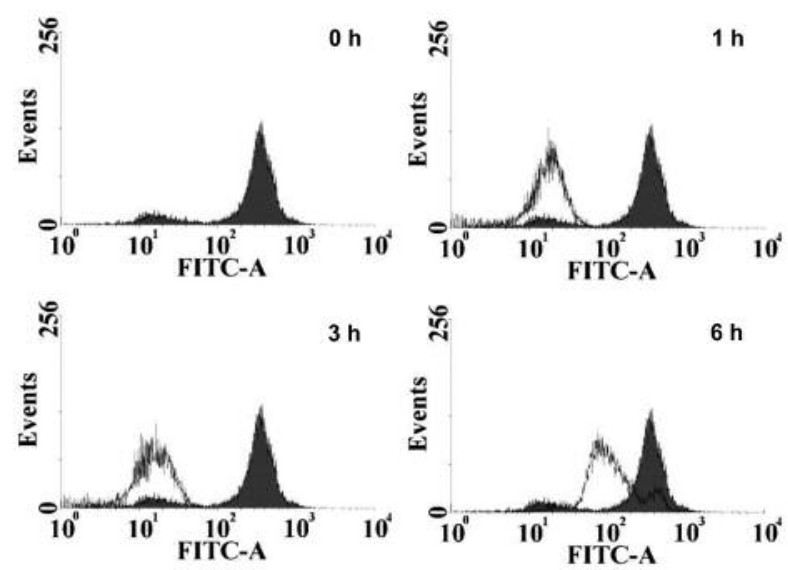

Figure 4. Pipoxolan-induced reactive oxygen species (ROS) generation and apoptosis are blocked by N-acetyl-L-cysteine (NAC). A. TW206 cells were incubated with $20 \mu \mathrm{g} / \mathrm{ml}$ of pipoxolan for 1,3 and $6 \mathrm{~h}$. The fluorescence of oxidized 2',7'-dichlorofluorescin was determined by flow cytometry. B: Cells were pre-treated with NAC $(10 \mathrm{mM})$ for $1 \mathrm{~h}$ and then incubated with $20 \mu \mathrm{g} / \mathrm{ml}$ pipoxolan for $24 \mathrm{~h}$. C: TW206 cells were incubated with $20 \mu \mathrm{g} / \mathrm{ml}$ of pipoxolan for 1,3 and $6 \mathrm{~h}$. Mitochondrial membrane permeability potential was measured by using a fluorescent dye, $\mathrm{DiOC}_{6}$, and was determined by flow cytometry. Values represent means $\pm S E M$ of three-independent experiments each performed in triplicate. ${ }^{*} p<0.01$, significantly different from the corresponding pipoxolan treatment alone. FITC-A: Fluorescein isothiocyanate-A.

however, resistance develops as the treatment continues, causing tumor relapse and treatment failure (24). Hence it is critical to explore other effective agents used in combination with present chemotherapeutic agents to sensitize their therapeutic effect. Pipoxolan could have the potential to be a novel anti-OSCC drug as it contains a dioxolan moiety which has been reported to induce apoptosis of various cancer cells $(20,21)$. In this study, we explored the role of pipoxolan in cytotoxicity toward OSCC in vitro, and elucidated its underlying mechanisms. Compared to Cal-27 (HNSCC) cells, TW206 and HSC-3 (OSCC) were found to be more sensitive to pipoxolan (Figure 2). Encouragingly, pipoxolan exerted its cytotoxicity by apoptosis of both TW206 (Figure 2C, 3A and B) and HSC-3 cell (Figure 3C and D). Pipoxolan induces the generation of ROS, in turn, triggering mitochondrial dysfunction and activating apoptotic components, leading to apoptosis (Figure 4). The molecular signals suggest that pipoxolan might initiate apoptosis through the intrinsic apoptotic pathway and PI3K/AKT signaling (Figure 5). 


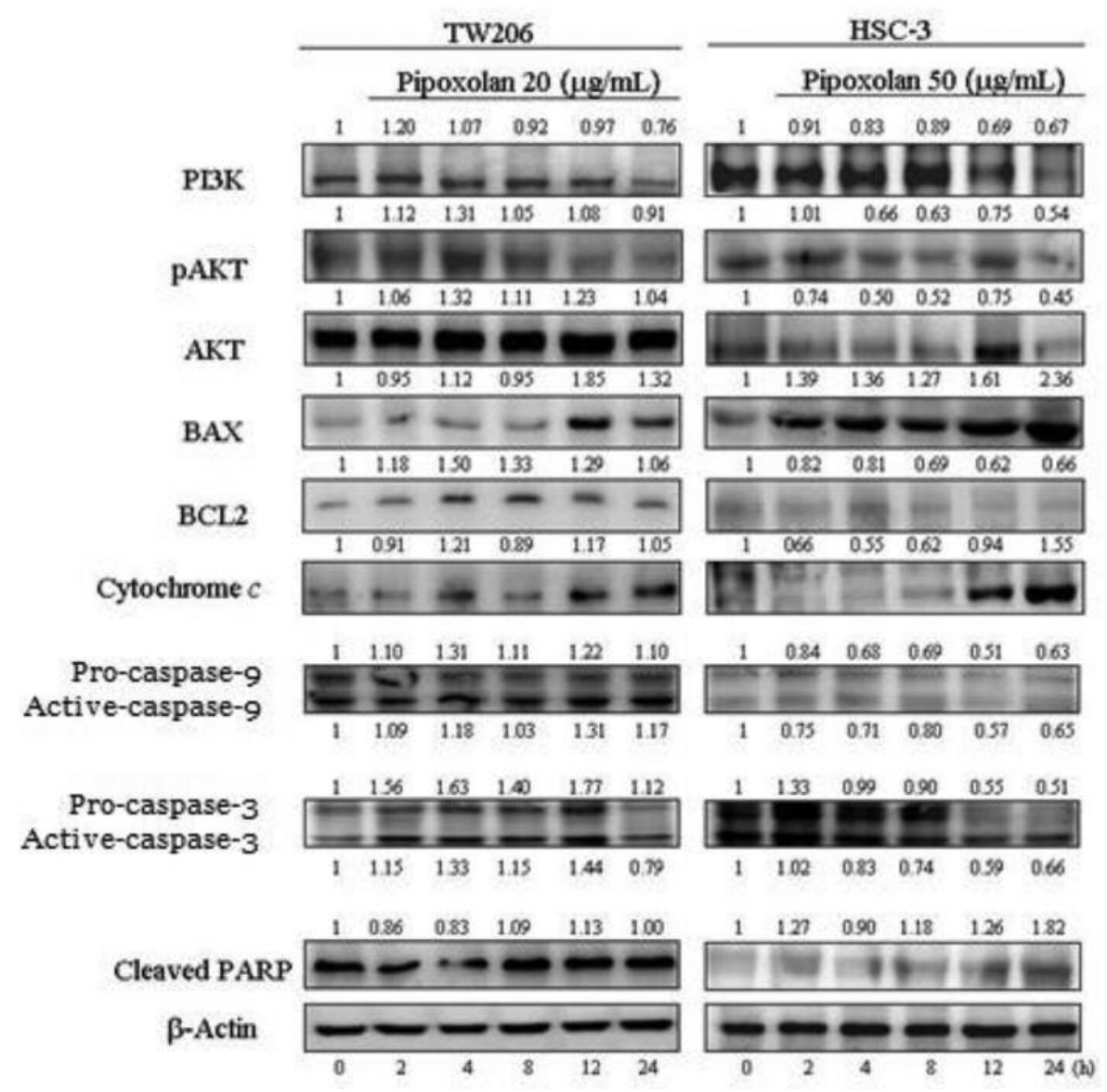

Figure 5. Pipoxolan affected the levels of the associated proteins of both the intrinsic and apoptotic pathways in TW206 and HSC-3 cells. TW-206 $(20 \mu \mathrm{g} / \mathrm{ml})$ and $\mathrm{HSC}-3(50 \mu \mathrm{g} / \mathrm{ml})$ were treated with pipoxolan for $0,2,4,8,12,24$ and $48 \mathrm{~h}$. Then cytosolic proteins or whole-cell lysates were prepared and subjected to western blotting. A: Protein expression of phosphatidylinositol-4,5-bisphosphate 3-kinase (PI3K), phosphorylated protein kinase B (pAKT), B-cell lymphoma 2 (BCL2), BCL2-like protein 4 (BAX), cytochrome c, caspase-9 and caspase-3 were analyzed in TW206 and HSC-3 cells by bestern blotting. $\beta$-Actin served as the loading control. The number above each blot indicates the intensity of the protein expression.

Under physiological conditions, the maintenance of a stable intracellular ROS level is essential keeping cell proliferation and redox balance (25). If the redox equilibrium becomes imbalanced, persistent oxidative stress favoring carcinogenesis will develop (26). Moreover, patients suffering from OSCC have been reported to carry higher rates of lipid peroxidation and low antioxidant levels (27). The cell-damaging property of ROS and the increased ROS generation by cancer cells may provide an opportunity to develop the cell killing potential of ROS by using exogenous ROS-stressing agents to increase the intracellular ROS to a toxic level, or the threshold that triggers cell death. Because it has been demonstrated that there is a causal relationship between ROS production and a loss of MMP (28). Evidence supports that ROS-inducing anticancer agents may affect various signaling pathways and genes that modulate carcinogenesis (29). ROS is reported to be involved in the early stages of apoptosis (30), causing a loss of MMP (31). Upon ROS stimulation, cytochrome $c$ is released from mitochondria into the cytoplasm. This leads to the activation of caspase-9, caspase-3, and PARP, resulting in apoptosis (32). Our observations suggest that pipoxolan treatment causes a redox imbalance, leading to overproduction of ROS. Based on the flow cytometric results, we demonstrated that pipoxolan induced ROS level in the OSCC in a time-dependent manner (Figure 4A). Accordingly, ROS seems to be involved in pipoxolan-induced cytotoxicity in oral cancer cells. Meanwhile, our result demonstrate that pipoxolan significantly reduced the MMP in OSCC in a time-dependent manner (Figure 4C). These results suggest that pipoxolan is capable of induction of mitochondrial depolarization, and that MMP loss could be affected directly or indirectly by ROS generation in oral cancer cells. The mechanism accounting for ROS 


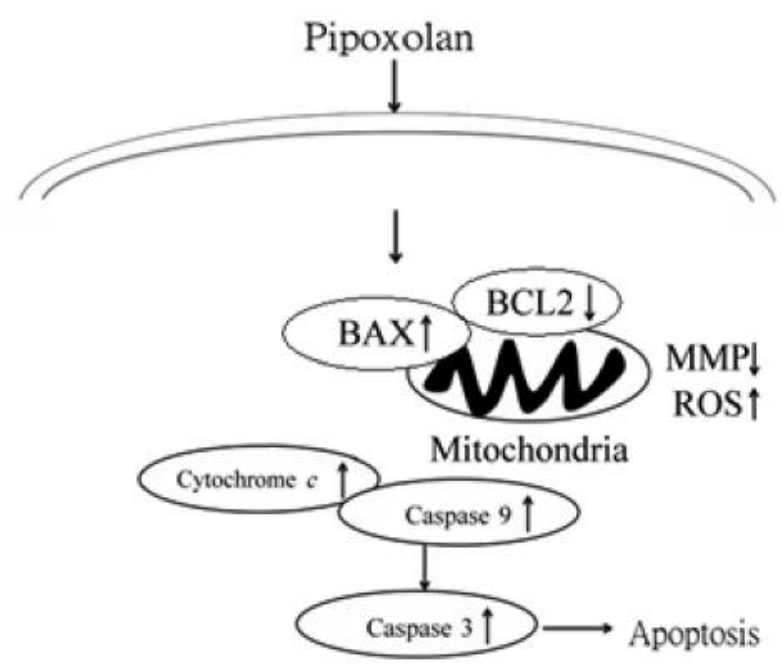

Figure 6. Hypothetic schematic of signaling transduction for the effects of pipoxolan on oral squamous cell carcinoma cells.

overproduction in OSCC remains uncertain. There are several factors contributing to the increased production of ROS in cancer cells such as oncogenic signals, mitochondrial dysfunction, and active metabolism (33).

The effects of pipoxolan on TW206 and HSC-3 OSCC cells are through both intrinsic but not extrinsic apoptotic pathways. Many investigators have suggested that FAS/CD95 is involved in the induction of apoptosis in mammalian cells (34). Binding of FAS to the FADD stimulates the recruitment of caspase- 8 . Caspase- 8 then activates caspase- 3 and other downstream caspases (35). Our results demonstrated that pipoxolan induced a timedependent increase of FAS/CD95 proteins (data not shown). However, alteration of caspase- 8 protein expression in these cells was not found under pipoxolan treatment (data not shown). This information implies the involvement the intrinsic but not extrinsic apoptotic signaling in both TW206 and HSC-3 cells pathway in the effects of pipoxolan.

BCL2 family, including BCL2 and BAX, play important roles in regulating proteins to activate the caspase cascade (36). The expression of BAX (pro-apoptotic protein) was significantly increased in TW206 and HSC-3 cells after 24 $\mathrm{h}$ incubation with 20 and $50 \mu \mathrm{g} / \mathrm{ml}$ pipoxolan, respectively (Figure 5). In contrast, BCL2 (antiapoptotic protein) considerably decreased. Cytochrome $c$ was also increased in both TW206 and HSC-3 cells after $12 \mathrm{~h}$ incubation with pipoxolan, respectively (Figure 5). If mitochondria recognize apoptotic signaling, BCL2 family members located on the mitochondrial membrane alter the MMP and trigger the release of cytochrome $c$ (37). Once released into the cytoplasm during the early stages of apoptosis, cytochrome $c$ activates post-mitochondrial caspase cascade, causes the DNA fragmentation and leads to apoptotic cell death (38). As shown, pipoxolan (20, and $50 \mu \mathrm{g} / \mathrm{ml}$ ) treatment caused a time-dependent increase in the cytosolic cytochrome $c$ in both TW206 and HSC-3 cells (Figure 5). Following treatment with pipoxolan, the cleavage of procaspase- 9 and pro-caspase- 3 into catalytically active forms were also clearly detected in a time-dependent manner (Figure 5). Our data suggest that pipoxolan activates the intrinsic apoptotic pathway of caspase-9/caspase-3 cascade in both TW206 and HSC-3 cells.

The activation of factors of the PI3K/AKT signaling pathway are noted in many cancer types, and $35-92 \%$ of OSCC tumors stain positively for phosphorylation of AKT (39). PI3K, a dimeric enzyme, composes of a regulatory (p85) and a catalytic (p110) subunit. The p85 subunit is anchored to ERBB receptor docking sites, and the p110 subunit is responsible for the phosphorylation and activation of AKT (39). The pAKT is an important factor for the prediction of poor clinical outcome in OSCC, because it is correlated with lymph node metastasis, clinical stage and Ecadherin expression (40). The activation of AKT signaling in OSCC is probably associated with the activation of epidermal growth factors or other factors (41). Inhibition of EGFR signaling appears to be a novel therapeutic strategy for the treatment of OSCC. Currently, the EGFR-directed inhibitor cetuximab is the solely approved targeted therapy for the treatment of OSCC. EGFR status may affect patient response to cetuximab treatment (41). Evidence also suggests that anthracycline therapies can be more effective for treatment of OSCC when combined with inhibitors of the PI3K/AKT pathway (7). Knockdown of fibroblast activation protein inactivated PTEN/PI3K/AKT and its downstream signaling, regulating proliferation, migration, and invasion of OSCC cells (42).

In conclusion, pipoxolan is cytotoxic against human OSCC cells, and this involves caspase-dependent apoptosis by a ROS-mediated mechanism and PI3K/AKT signal transduction. Fuurther study on the synthesis of compounds with dioxolane might develop novel antitumor agents against OSCC cells.

\section{Conflicts of Interest}

The Authors declare no conflicts of interest interest in regard to this study.

\section{Acknowledgements}

This work was supported by Grants from the Ministry of Science and Technology (MOST 103-2320-B-039-026; MOST104-2320-B039-007) and China Medical University (CMU100-ASIA-18). The Authors also appreciate English assistance from Stephen Hsu, and technical assistance from Hsiao Jun-Han and Sung Jie-Ru. 


\section{References}

1 Peng Q, Wang Y, Quan H, Li Y and Tang Z: Oral verrucous carcinoma: From multifactorial etiology to diverse treatment regimens (Review). Int J Oncol 49(1): 59-73, 2016.

2 Chang JW, Kang SU, Shin YS, Seo SJ, Kim YS, Yang SS, Lee JS, Moon E, Lee K and Kim C-H: Combination of NTP with cetuximab inhibited invasion/migration of cetuximab-resistant OSCC cells: Involvement of NF-kB signaling. Sci Rep 5: 18208, 2015.

3 Poljsak B, Šuput D and Milisav I: Achieving the balance between ROS and antioxidants: when to use the synthetic antioxidants. Oxid Med Cell Longev 2013: 956792, 2013.

4 Martinez-Useros J, Li W, Cabeza-Morales M and GarciaFoncillas J: Oxidative stress: a new target for pancreatic cancer prognosis and treatment. J Clin Med 6(3): 29, 2017.

5 Kawanishi S, Hiraku Y, Pinlaor S and Ma N: Oxidative and nitrative DNA damage in animals and patients with inflammatory diseases in relation to inflammation-related carcinogenesis. Biol Chem 387(4): 365-372, 2006.

6 Smolensky D, Rathore K, Bourn J and Cekanova M: Inhibition of the PI3K/AKT pathway sensitizes oral squamous cell carcinoma cells to anthracycline-based chemotherapy in vitro. J Cell Biochem, 2016. doi: 10.1002/jcb.25747. [Epub ahead of print]

7 Yen CY, Chiu CC, Haung RW, Yeh CC, Huang KJ, Chang KF, Hseu YC, Chang FR, Chang HW and Wu YC: Antiproliferative effects of goniothalamin on Ca9-22 oral cancer cells through apoptosis, DNA damage and ROS induction. Mutat Res 747(2): 253-258, 2012.

8 Tait SWG and Green DR: Cell survival in tough times: The mitochondrial recovery plan. Cell Cycle 9(21): 4254-4255, 2010

9 Adams JM: Ways of dying: multiple pathways to apoptosis. Genes Dev 17(20): 2481-2495, 2003.

10 Boatright KM and Salvesen GS: Mechanisms of caspase activation. Curr Opin Cell Biol 15(6): 725-731, 2003.

11 Nagata S: Apoptosis by death factor. Cell 88(3): 355-365, 1997.

12 Guerrero AD, Chen M and Wang J: Delineation of the caspase9 signaling cascade. Apoptosis 13(1): 177-186, 2008.

13 Simpson DR, Mell LK and Cohen EEW: Targeting the $\mathrm{PI} 3 \mathrm{~K} / \mathrm{AKT} / \mathrm{mTOR}$ pathway in squamous cell carcinoma of the head and neck. Oral Oncol 51(4): 291-298, 2015.

14 Horn D, Hess J, Freier K, Hoffmann J and Freudlsperger C: Targeting EGFR-PI3K-AKT-mTOR signaling enhances radiosensitivity in head and neck squamous cell carcinoma. Expert Opin Ther Targets 19(6): 795-805, 2015.

15 Jeon YJ, Cho JH, Lee SY, Choi YH, Park H, Jung S, Shim JH and Chae JI: Esculetin induces apoptosis through EGFR/ $\mathrm{PI} 3 \mathrm{~K} / \mathrm{AKT}$ signaling pathway and nucleophosmin relocalization. J Cell Biochem 117(5): 1210-1221, 2016.

16 Harada K, Ferdous T, Harada T and Ueyama Y: Metformin in combination with 5-fluorouracil suppresses tumor growth by inhibiting the Warburg effect in human oral squamous cell carcinoma. Int J Oncol 49(1): 276-284, 2016.

17 Chlud K: Clinical experiences with a new spasmolytic, Rowapraxin. Med Welt 33: 1801-1803, 1969.

18 Terasoma K and Takahashi Y: Analgesic effect of Rowapraxin (BR18) in urological diseases. Hinyokika Kiyo 17(9): 592-595, 1971.

19 Chen YF, Yang JS, Huang WW and Tsai HY: Novel antileukemia activities of pipoxolan operate via the mitochondriarelated pathway in human leukemia U937 cells and attenuate
U937 cell growth in an animal model. Mol Med Rep 3(5): 851856, 2010.

20 Sheu MJ, Chou PY, Huang CS, Tsai IC, Chien YC, Lin SY, Tsai $\mathrm{HY}$, Cheng $\mathrm{HC}$ and $\mathrm{Wu} \mathrm{CH}$ : Pipoxolan inhibits proliferation of HL-60 human leukaemia cancer cells by arresting the cell cycle at the G0/G1 phase. Clin Exp Pharmacol Physiol 37(5-6): 605612, 2010.

21 Lee MM, Chen YY, Liu PY, Hsu S and Sheu MJ: Pipoxolan inhibits CL1-5 lung cancer cells migration and invasion through inhibition of MMP-9 and MMP-2. Chem Biol Interact 236: 1930, 2015.

22 Chen YF, Tsai HY, Wu KJ, Siao LR and Wood WG: Pipoxolan ameliorates cerebral ischemia via inhibition of neuronal apoptosis and intimal hyperplasia through attenuation of VSMC migration and modulation of matrix metalloproteinase-2/9 and Ras/MEK/ERK signaling pathways. PloS One 8(9): e75654, 2013.

23 Ye J, Wang S, Leonard SS, Sun Y, Butterworth L, Antonini J, Ding M, Rojanasakul Y, Vallyathan V and Castranova V: Role of reactive oxygen species and p53 in chromium (VI)-induced apoptosis. J Biol Chem 274(49): 34974-34980, 1999.

24 Wang B, Zhang S, Yue K and Wang X-D: The recurrence and survival of oral squamous cell carcinoma: a report of 275 cases. Chin J Cancer 32(11): 614-618, 2013.

25 Martin KR and Barrett JC: Reactive oxygen species as doubleedged swords in cellular processes: low-dose cell signaling versus high-dose toxicity. Hum Exp Toxicol 21(2): 71-75, 2002.

26 Ameziane-El-Hassani $\mathrm{R}$ and Dupuy C: Detection of reactive oxygen species in cells undergoing oncogene-induced senescence. Methods Mol Biol 1534: 139-145, 2017.

27 Khanna R, Thapa PB, Khanna HD, Khanna S, Khanna AK and Shukla HS: Lipid peroxidation and antioxidant enzyme status in oral carcinoma patients. Kathmandu Univ Med J 3(4): 334-339, 2005.

28 Liu WH and Chang LS: Reactive oxygen species and p38 mitogen-activated protein kinase induce apoptotic death of U937 cells in response to Naja nigricollis toxin-gamma. J Cell Mol Med 13(8B): 1695-1705, 2009.

29 Safe S and Kasiappan R: Natural products as mechanism-based anticancer agents: $\mathrm{Sp}$ transcription factors as targets. Phytother Res 30(11): 1723-1732, 2016.

30 Samhan-Arias AK, Martín-Romero FJ and Gutiérrez-Merino C: Kaempferol blocks oxidative stress in cerebellar granule cells and reveals a key role for reactive oxygen species production at the plasma membrane in the commitment to apoptosis. Free Radic Biol Med 37(1): 48-61, 2004.

$31 \mathrm{Oh} \mathrm{S-H}$ and Lim S-C: A rapid and transient ROS generation by cadmium triggers apoptosis via caspase-dependent pathway in HepG2 cells and this is inhibited through $N$-acetylcysteinemediated catalase upregulation. Toxicol Appl Pharmacol 212(3): 212-223, 2006.

32 Tait SWG and Green DR: Mitochondria and cell death: outer membrane permeabilization and beyond. Nat Rev Mol Cell Biol 11(9): 621-632, 2010.

33 Trachootham D, Zhou Y, Zhang H, Demizu Y, Chen Z, Pelicano H, Chiao PJ, Achanta G, Arlinghaus RB and Liu J: Selective killing of oncogenically transformed cells through a ROSmediated mechanism by $\beta$-phenylethyl isothiocyanate. Cancer Cell 10(3): 241-252, 2006. 
34 Glaser T, Wagenknecht B and Weller M: Identification of p21 as a target of cycloheximide-mediated facilitation of CD95mediated apoptosis in human malignant glioma cells. Oncogene 20(35): 4757-4767, 2001.

35 Fuchs EJ, McKenna KA and Bedi A: p53-dependent DNA damage-induced apoptosis requires Fas/APO-1-independent activation of CPP32 3 . Cancer Res 57(13): 2550-2554, 1997.

36 Zheng JH, Viacava Follis A, Kriwacki RW and Moldoveanu T: Discoveries and controversies in BCL-2 protein-mediated apoptosis. FEBS J 283(14): 2690-2700, 2016.

37 Adams JM and Cory S: The BCL2 protein family: arbiters of cell survival. Science 281(5381): 1322-1326, 1998.

38 Fan J, Zhang N, Yin G, Zhang Z, Cheng G, Qian W, Long H and Cai W: Edaravone protects cortical neurons from apoptosis by inhibiting the translocation of BAX and increasing the interaction between 14-3-3 and p-BAD. Int J Neurosci 122(11): 665-674, 2012.

39 Lim J, Kim JH, Paeng JY, Kim MJ, Hong SD, Lee JI and Hong SP: Prognostic value of activated Akt expression in oral squamous cell carcinoma. J Clin Pathol 58(11): 1199-1205, 2005.

40 Bussink J, van der Kogel AJ and Kaanders JHAM: Activation of the PI3-K/AKT pathway and implications for radioresistance mechanisms in head and neck cancer. Lancet Oncol 9(3): 288296, 2008.
41 Kimura I, Kitahara H, Ooi K, Kato K, Noguchi N, Yoshizawa $\mathrm{K}$, Nakamura $\mathrm{H}$ and Kawashiri S: Loss of epidermal growth factor receptor expression in oral squamous cell carcinoma is associated with invasiveness and epithelial-mesenchymal transition. Oncol Lett 11(1): 201-207, 2016.

42 Wang H, Wu Q, Liu Z, Luo X, Fan Y, Liu Y, Zhang Y, Hua S, $\mathrm{Fu} \mathrm{Q}$ and Zhao M: Down-regulation of FAP suppresses cell proliferation and metastasis through PTEN/PI3K/AKT and RASERK signaling in oral squamous cell carcinoma. Cell Death Dis 5: e1155, 2014.

43 Yarden Y and Sliwkowski MX: Untangling the ERBB signalling network. Nat Rev Mol Cell Biol 2(2): 127-137, 2001.
Received April 10, 2017

Revised May 1, 2017

Accepted May 2, 2017 